\title{
PENGARUH PROFITABILITAS TERHADAP HARGA SAHAM EMITEN SEKTOR INDUSTRI BARANG KONSUMSI YANG TERDAFTAR DI BURSA EFEK INDONESIA TAHUN 2017-2019
}

\author{
Marsitiana Ayu ${ }^{(1)^{*}}$, Nelson $^{(2)}$ \\ Fakultas Ekonomi Universitas Sang Bumi Ruwa Jurai \\ *email: maristianaayu @gmail.com.nelson@gmail.com
}

\begin{abstract}
Abstrak. Penelitian ini bertujuan untuk mengetahui profitabilitas terhadap harga saham emitmen sector industry barang konsumsi yang terdaftar di Bursa Efek Indonesia Tahun 2017-2019. Jenis penelitian yang digunakan dalam penelitian ini menggunakan deskriptif kuantitatif. Metode pengumpulan data dalam penelitian ini menggunakan studi dokumentasi dan kepustakaan. Penelitian ini menggunakan jenis penelitian deskriptif kuantitatif. Jumlah perusahaan sektor industri barang konsumsi yang terdaftar di Bursa Efek Indonesia adalah sebanyak 53 perusahaan yang merupakan jumlah populasi dalam penelitian ini Teknik analisis yang digunakan menggunakan regresi linear sederhana. Berdasarkan hasil penelitian diketahui bahwa Return On Asset (ROA) berpengaruh positif terhadap harga saham perusahaan sektor industri barang konsumsi pada tahun 2017-2019.
\end{abstract}

Kata Kunci: Profitabilitas, Harga Saham, Bursa Efek Indonesia

Abstract. This study aims to determine the profitability of the share price of the consumer goods industry sector listed on the Indonesia Stock Exchange in 2017-2019. The type of research used in this research is descriptive quantitative. Methods of data collection in this study using documentation and literature studies. This research uses quantitative descriptive research. The number of consumer goods industrial sector companies listed on the Indonesia Stock Exchange is 53 companies which are the total population in this study. The analysis technique used uses simple linear regression. Results Based on the research, it is known that Return On Assets (ROA) has a positive effect on stock prices of companies in the consumer goods industry sector in 2017-2019.

Keywords: Profitability, Stock Price, Indonesia Stock Exchange

\section{PENDAHULUAN}

Salah satu sarana untuk melakukan investasi adalah pasar modal, pasar modal memberikan peran besar bagi perekonomian suatu negara karena pasar modal menjalankan dua fungsi sekaligus, yaitu fungsi ekonomi dan fungsi keuangan. Pasar modal merupakan sarana penghubung antara dua pihak yang memiliki kepentingan berbeda yakni, investor dengan perusahaan. Investor merupakan pihak yang memiliki dana sedangkan perusahaan merupakan pihak yang memerlukan dana.
Pasar modal menurut Fahmi (2012:55) ialah "tempat berbagai pihak, khususnya perusahaan menjual saham (stock) dan obligasi (bond), dengan tujuan dari hasil penjualan tersebut nantinya akan dipergunakan sebagai tambahan dana atau memperkuat modal perusahaan". Pasar modal sendiri merupakan alternatif pembiayaan untuk mendapatkan modal dengan biaya yang relatif murah dan juga tempat untuk investasi jangka pajang dan jangka pendek. Para penanam dana dan perusahaan bertemu di pasar modal dalam rangka tawar menawar surat berharga. 
Dalam pasar modal terdapat beberapa instrumen keuangan atau sekuritas yang diperjualbelikan. Berdasarkan UndangUndang Pasar Modal (UUPM) Pasal 1 ayat 5 diantaranya adalah surat pengakuan utang, surat berharga komersial, saham, obligasi, tanda bukti utang, unit penyerta kontrak investasi kolektif (reksadana), kontrak berjangka atas efek (option), dan setiap derivatif dari efek. Bagi perusahaan yang telah go public dengan menerbitkan saham dan menjualnya kepada investor melalui Bursa Efek Indonesia (BEI), pasar modal merupakan sumber dana untuk meningkatkan permodalan. Sedangkan bagi investor, pasar modal merupakan tempat untuk menanamkan dana pada suatu perusahaan atau emiten dengan membeli saham perusahaan yang dikehendaki yang kemudian hal ini disebut dengan investasi. Investor ini melakukan investasi dengan membeli saham perusahaan dengan harapan untuk mendapatkan keuntungan investasi yang sesuai dengan apa yang telah diinvestasikannya. Keuntungan yang diperoleh investor dari penanaman modal saham ini dapat berasal dari laba perusahaan yang dibagikan atau deviden, dan kenaikan atau penurunan harga saham.

Saham dapat dikatakan sebagai tanda kepemilikan seseorang atau badan dalam suatu perusahaan. Saham dikeluarkan oleh emiten yang telah go pulic dan sudah terdaftar di Bursa Efek Indonesia (BEI). Penerbitan saham oleh perusahaan merupakan upaya dalam mendapatkan tambahan dana. Husnan dan Pudjiastuti (2006:7) mengemukakan bahwa "Bagi perusahaan yang mengeluarkan saham di pasar modal, harga saham yang diperjualbelikan di bursa merupakan indikator nilai perusahaan." Saham diperjualbelikan melalui sarana pasar modal yang di Indonesia disebut dengan Bursa Efek. Bursa tersebut tidak membeli atau menjual saham-saham yang ada, melainkan bursa hanya merupakan tempat atau sarana bagi para investor untuk bertransaksi didalamnya.

Dalam Bursa Efek Indonesia (BEI) terdapat beberapa sektor perusahaan yang memperjualbelikan sahamnya, salah satu sektor yang mempunyai peran aktif dipasar modal adalah sektor industri barang konsumsi. Dimana sektor industri barang konsumsi merupakan salah satu sektor dari perusahaan manufaktur. Investasi pada industri barang konsumsi merupakan investasi yang cukup menjanjikan di Indonesia. Perusahaan industri barang konsumsi mempunyai prospek usaha yang cukup baik. Dilihat dari kinerja perusahaan dapat bersaing dipasar global yang sangat berpengaruh terhadap perekonomian negara, hal tersebut dikarenakan sahamsaham dari perusahaan-perusahaan dalam indusri barang konsumsi yang masih menawarkan potensi kenaikan. Produkproduk yang dihasilkan tersebut bersifat konsumtif dan disukai orang sehingga para produsen dalam industri ini memiliki tingkat penjualan yang tinggi yang berdampak pula pada perkembangan sektor industri ini. Sektor industri merupakan salah satu sektor yang mempunyai peranan penting dalam perekonomian Indonesia. Sektor industri diyakini sebagai sektor yang dapat memimpin dibandingkan dengan sektorsektor lain. Produk industri selalu memiliki nilai tukar yang tinggi serta menciptakan nilai tambah yang lebih besar dibandingkan produk-produk lain. Hal ini disebabkan karena sektor industri memiliki variasi produk yang sangat beragam dan mampu memberikan manfaat yang tinggi pada pemakainya (Wyanov, 2012).

Sektor industri barang dan konsumsi merupakan salah satu sektor industri yang terdapat di Bursa Efek Indonesia (BEI) yang diyakini sampai saat ini berhasil 
mempertahankan kehidupan bisnisnya dikarenakan sifatnya yang menjadi kebutuhan dasar yang diperlukan masyarakat sehingga pertumbuhan sektor ini dapat dikatakan terus meningkat.

Sektor industri barang konsumsi, terdapat beberapa subsektor, yaitu subsektor makanan \& minuman, subsektor rokok, subsektor peralatan rumah tangga, subsektor kosmetik \& keperluan rumah tangga, dan subsektor farmasi, dan subsektor lainnya. Untuk lebih jelas dan lengkap, berikut pemaparannya. Daftar emiten di sini paling terbaru yaitu terhitung Januari 2020

Seluruh sub sektor yang ada pada sektor Industri Barang Konsumsi merupakan para produsen dari produkproduk kebutuhan mendasar konsumen, seperti makanan, minuman, obat, daging, dan produk toiletries. Produk-produk yang dihasilkan tersebut bersifat konsumtif dan disukai orang sehingga para produsen dalam industri ini memiliki tingkat penjualan yang tinggi yang berdampak pula terhadap pertumbuhan di sektor industri ini.

Indeks manufaktur yang sebagian besar komponen pembentuknya terdiri dari perusahaan yang bergerak di industri barang konsumsi, industri dasar, dan aneka industri terus mengalami kenaikan. Sektor industri barang konsumsi menopang pertumbuhan manufaktur, sebagian besar terbentuk dari industri barang konsumsi. Pekembangan indeks industri Sektor Industri Barang Konsumsi di Bursa Efek Indonesia mengalami kenaikan dari tahun 2017-2019, akan tetapi di tahun 2019 mengalami penurunan, penurunan yang dialami oleh sektor industri barang konsumsi mencapai $0,36 \%$ itu disebabkan oleh menjelangya pemilu. Akan tetapi mengalami kenaikan kembali menjelang Idul Fitri. Sektor ini membuktikan bahwa walaupun sempat mengalami penurunan tetapi dapat memperbaiki dengan cepat penyebab melambatnya pertumbuhan pasar industri tersebut, dan hasil yang didapat adalah sektor ini kembali mengalami kenaikan yang berarti bahwa kinerja perusahaan pada sektor tersebut terus membaik.

Harga saham merupakan salah satu indikator pengelolaan perusahaan. Keberhasilan dalam menghasilkan keuntungan akan memberikan kepuasan bagi investor yang rasional. Harga saham yang cukup tinggi akan memberikan keuntungan, yaitu berupa capital gain dan citra yang lebih baik bagi perusahaan sehingga perubahan naik turun dari satu waktu ke waktu yang lain. Perubahaan tersebut tergantung pada kekuatan permintaan dan penawaran. Apabila suatu saham mengalami kelebihan permintaan, maka harga saham akan cenderung naik. Sebaliknya, apabila kelebihan penawaran, maka harga saham cenderung turun. Irham Fahmi (2013: 276 ), ada beberapa kondisi dan situasi yang menentukan suatu saham itu akan mengalami naik dan turun/ fluktuasi, yaitu:

1. kondisi mikro dan makro ekonomi

2. kebijakan perusahaan dalam memutuskan untuk ekspansi (perluasan usaha), seperti membuka kantor cabang (brand office), kantor cabang pembantu (sub brand office) baik yang dibuka di domestik maupun luar negeri,

3. pergantian direksi secara tibatiba,

4. adanya direksi atau pihak komisaris perusahaan yang terlibat tindak pidana dan kasusnya sudah masuk ke pengadilan,

5. kinerja perusahaan yang terus mengalami penurunan dalam setiap waktunya,

6. risiko sistematis, yaitu suatu bentuk risiko yang terjadi secara menyeluruh dan telah ikut 
menyebabkan perusahaan ikut terlibat,

7. efek dari psikologi pasar yang ternyata mampu menekan kondisi teknikal jual beli saham.

Menurut Sartono (2005:85) harga saham adalah suatu jenis surat berharga jangka panjang untuk memenuhi kebutuhan jangka panjang. Harga Saham adalah surat bukti atau tanda kepemilikan bagian modal suatu perseroan terbatas (Siamat,2006:268). Harga saham adalah nilai suatu saham yang mencerminkan kekayaan perusahaan untuk mengeluarkan saham, di mana perubahan atau fluktuasinya sangat ditentukan penawaran dan permintaan yang terjadi di pasar bursa (Husnan,2001:30). Sedangkan menurut (Jogiyanto 2008:167) harga saham adalah harga suatu saham yang terjadi di pasar bursa pada saat tertentu yang ditentukan oleh pelaku pasar dan ditentukan oleh permintaan dan penawaran saham yang bersangkutan di pasar modal. Harga saham suatu perusahaan ditentukan oleh demand dan supply antara penjual dan pembeli. Biasanya demand dan supply ini dipengaruhi oleh faktor internal maupun eksternal perusahaan. Faktor internal merupakan faktor yang berhubungan dengan tingkat kinerja perusahaan yang dapat dikendalikan oleh manajemen perusahaan. Faktor internal tersebut seperti kebijakan dividen dan profitabilitas perusahaan. Berikut ini adalah perkembangan harga saham emiten Sektor Industri Barang Konsumsi yang memiiliki trend peningkatan Tahun 2017-2019

Kinerja harga saham perusahaan sektor Industri Barang Konsumsi mengalami kenaikan. Rata-rata keseluruhan harga saham selama Tahun 2017-2019 adalah Rp 4701.992 dengan rata-rata harga saham meningkat setiap tahun. Kenaikan harga saham terbesar berasal pada Tahun 2018 dari Multi
Bintang (MLBI) dan penurunan harga saham terendah berasal dari Indofood CBP (ICBP). Peningkatan harga saham ini dapat mencerminkan kenaikan profitabilitas perusahaan. Profitabilitas merupakan hasil bersih dari sejumlah kebijakan dan keputusan perusahaan. Rasio profitabilitas mengukur seberapa besar kemampuan perusahaan dalam menghasilkan laba.

Menurut Fahmi

(2014:81) "profitabilitas digunakan untuk mengukur efektivitas manajemen secara keseluruhan yang ditunjukan oleh besar kecilnya tingkat keuntungan yang di peroleh dalam hubungannya dengan pejualan maupun investasi". Bisa dikatakan bahwa semakin besar profitabilitas, semakin besar pula keuntungannya yang dicapai perusahaan tersebut dan semakin baik pula posisi perusahaan tersebut dari segi penggunaan aspek. Maka dari itu, semakin tinggi profitabilitas perusahaan maka akan membuat harga saham juga berpengaruh.

Indikator yang digunakan dalam penelitian ini untuk mengukur profitabilitas adalah return on equity (ROE). Penggunaan rasio tersebut dikarenakan ROE mampu mengukur kemampuan perusahaan menghasilkan laba atas pengembalian dari modal yang telah ditanam. Return on equity menggambarkan kemampuan perusahaan dalam memberikan keuntungan bagi pemegang saham biasa (pemilik modal) dengan menunjukkan persentase laba bersih yang tersedia untuk modal pemegang saham yang telah digunakan perusahaan. Tanpa berada dalam keadaan untung (profit), maka perusahaan akan sangat sulit menarik modal dari luar perusahaan. Hubungan antara harga saham dan profitabilitas dalam penelitian Amanah et al., (2014) menyatakan bahwa profitabilitas memiliki pengaruh yang siginfikan terhadap harga saham. Sedangkan dalam penelitian Meythi et al., 
(2011) menyatakan bahwa profitabilitas tidak memiliki pengaruh signifikan terhadap harga saham.

Laba mengalami penurunan dari tahun 2018-2019. Turunnya rata-rata laba pada emiten industri barang konsumsi didorong oleh turunnya laba sebagian emiten, emiten yang mengalami penurunan dari Tahun 2018-2019 adalah Tiga Pilar Sejahtera (TPSF), Kedaung Indah Can (KICI), Merck Indonesia (MERK) dan Tempo Scan Pasific (TPSP). Emiten industri barang konsumsi menghasilkan penurunan laba dari tahun 2018-2019, artinya emiten ini memiliki kinerja yang kurang baik dalam menghasilkan laba. Besarnya ratarata laba akan mempengaruhi jumlah laba per lembar saham yang dibagikan dan besarnya laba bersih akan mempengaruhi pemegang saham

Berdasarkan penelitian sebelumnya oleh (Murdijaningsih and Wijaya 2018) menunjukan bahwa ROA berpengaruh positif terhadap harga saham perusahaan manufaktur sector industry barang konsumsi yang terdaftar pada tahun 20152017.

Hal ini sejalan dengan penelitian yang (Hisbullah 2021) membuktikan bahwa ROA dan NPM tidak memengaruhi harga saham. ROE merupakan faktor yang memberi pengaruh harga saham perusahaan sektor industri barang dan konsumsi pada tahun 2017-2020 secara positif signifikan.

Berdasarkan uraian di atas, maka peneliti tertarik untuk melakukan penelitian mengenai faktor yang berpengaruh terhadap harga saham yang masih menunjukkan hasil yang beragam antara hasil penelitian yang satu dengan yang lainnya sehingga menarik untuk diteliti lebih lanjut sebagai usaha untuk mendapatkan hasil yang lebih konsisten.
Dengan demikian, maka peneliti membuat suatu penelitian dengan judul "PENGARUH PROFITABILITAS TERHADAP HARGA SAHAM EMITEN SEKTOR INDUSTRI BARANG KONSUMSI YANG TERDAFTAR DI BURSA EFEK INDONESIA TAHUN 2017-2019".

\section{METODE PENELITIAN}

Penelitian ini menggunakan jenis penelitian deskriptif kuantitatif. Jumlah perusahaan sektor industri barang konsumsi yang terdaftar di Bursa Efek Indonesia adalah sebanyak 53 perusahaan yang merupakan jumlah populasi dalam penelitian ini Teknik analisis yang digunakan menggunakan regresi linear sederhana dengan rumus

$$
\begin{aligned}
& \mathbf{Y =} \mathbf{a}+\mathbf{b}+\mathbf{e} \\
& \text { Keterangan: } \\
& \mathrm{Y} \quad \text { = Variabel dependen (harga } \\
& \quad \text { saham closing price) } \\
& \mathrm{a} \quad \text { = Harga konstan } \\
& \mathrm{b} \quad \text { = Koefisien Regresi Variabel X } \\
& \mathrm{X} \quad \text { = Variabel Independen }
\end{aligned}
$$

\section{HASIL DAN PEMBAHASAN}

\section{Harga Saham}

Pada bagian ini akan dideskripsikan harga saham penutupan (closing price) akhir tahun dari 11 perusahaan sampel selama periode penelitian yakni Tahun 2017-2019, sehingga dapat diketahui perkembangan harga saham pada masing-masing emiten selama periode penelitian. Perkembangan harga saham dikatakan baik apabila harga saham mengalami kenaikan setiap tahunnya, dan sebaliknya perkembangan harga saham dikatakan tidak baik atau buruk apabila harga saham mengalami 
penurunan setiap tahunnya. Kinerja harga saham akan diuraikan dalam bentuk tabel pada Tabel 1:

Tabel 1.

Perkembangan Harga Saham Emiten Sektor Industri Barang Konsumsi 2017 2019

\begin{tabular}{lllllll}
\hline NO & EMITEN & $\mathbf{2 0 1 7}$ & $\mathbf{2 0 1 8}$ & $\mathbf{2 0 1 9}$ & jumlah & $\begin{array}{l}\text { Rata- } \\
\text { Rata }\end{array}$ \\
\hline $\mathbf{1}$ & DLTA & 3.900 & 5.200 & 5.000 & 14.100 & 4.700 \\
$\mathbf{2}$ & ICBP & 13.100 & 13.475 & 8.575 & 35.150 & 11.717 \\
$\mathbf{3}$ & INDF & 6.750 & 5.175 & 7.925 & 19.850 & 6.617 \\
$\mathbf{4}$ & MLBI & 11.950 & 8.200 & 11.750 & 31.900 & 10.633 \\
$\mathbf{5}$ & GGRM & 60.700 & 65.000 & 66.900 & 192.600 & 64.200 \\
$\mathbf{6}$ & HMSP & 66.650 & 67.000 & 68.830 & 202.480 & 67.493 \\
$\mathbf{7}$ & DVLA & 1.690 & 1.300 & 1.755 & 4.745 & 1.582 \\
$\mathbf{8}$ & KLBF & 1.830 & 1.320 & 1.515 & 4.665 & 1.555 \\
$\mathbf{9}$ & MERK & 1.600 & 6.775 & 9.200 & 17.575 & 5.858 \\
$\mathbf{1 0}$ & TSPC & 2.865 & 1.750 & 1.970 & 6.585 & 2.195 \\
$\mathbf{1 1}$ & UNVR & 32.300 & 37.000 & 38.800 & 108.100 & 36.033 \\
Maksimum & 66.650 & 67.000 & 68.800 & 202.450 & 67.483 \\
Minimum & 1.600 & 1.300 & 1.515 & 4.415 & 1.472 \\
\hline
\end{tabular}

Sumber: idx.co.id. Data diolah,2020

Tabel 1 menunjukkan 55 variasi harga saham penutupan (closing price) akhir tahun dari 11 emiten sektor industri barang konsumsi di Bursa Efek Indonesia Tahun 2017-2019. Harga saham tertinggi emiten sektor industri barang konsumsi selama Tahun 2017-2019 dimiliki oleh emiten HMSP, yakni sebesar Rp 59.900 pada Tahun 2017 Rp 66.650 pada Tahun 2018, Rp 67.000 pada Tahun 2018 dan Rp 68.800 pada Tahun 2019. Harga saham yang tinggi dan selalu mengalami kenaikan disetiap tahunnya menggambarkan bahwa emiten HMSP memiliki citra perusahaan yang baik, sehingga menarik investor untuk menanamkan sahamnya dan menyebabkan harga saham menjadi tinggi.

Harga saham terendah emiten sektor industri barang konsumsi selama Tahun
2017-2019 dimiliki oleh emiten KLBF, yakni sebesar Rp 1.060 pada Tahun 2017 dan sebesar Rp 1.250 pada Tahun 2018. Harga saham terendah pada tahun 2017 dimiliki oleh emiten MERK yakni sebesar Rp 1.600. Harga saham terendah pada tahun 2018 dimiliki oleh emiten DVLA yakni sebesar Rp 1.300. Harga saham terendah pada tahun 2019 emiten KLBF kembali memiliki harga saham terendah, yakni sebesar Rp 1.515.

Profitabilitas

\section{a. Return on Assets (ROA)}

Pada bagian ini akan dideskripsikan Return on Assets (ROA) dan Return on Equity (ROE) 11 perusahaan sampel selama periode penelitian yakni pada Tahun 20122016, sehingga diketahui perkembangan 
Return on Assets (ROA) dan Return on Equity (ROE) dari tahun ke tahun. Perkembangan profitabilitas dikatakan baik apabila Return on Assets (ROA) dan Return on Equity (ROE) stabil naik setiap tahunnya. Berikut akan diuraikan dalam bentuk tabel:

Tabel 2. Kinerja Return On Assets Emiten Sektor Industri Barang Konsumsi 2017-2019 (\%)

\begin{tabular}{clrrrrr}
\hline NO & EMITEN & 2017 & 2018 & 2019 & Jumlah & Rata-rata \\
\hline $\mathbf{1}$ & DLTA & 26,59 & 16,82 & 19,87 & 63,28 & 21,09 \\
$\mathbf{2}$ & ICBP & 9,59 & 10,04 & 11,84 & 31,47 & 10,49 \\
$\mathbf{3}$ & INDF & 3,85 & 4,9 & 5,75 & 14,5 & 4,83 \\
$\mathbf{4}$ & MLBI & 34,56 & 21,75 & 41,26 & 97,57 & 32,52 \\
$\mathbf{5}$ & GGRM & 7,69 & 9,82 & 9,75 & 27,26 & 9,09 \\
$\mathbf{6}$ & HMSP & 34,18 & 26,31 & 28,51 & 89 & 29,67 \\
$\mathbf{7}$ & DVLA & 14,3 & 15,89 & 22,79 & 52,98 & 17,66 \\
$\mathbf{8}$ & KLBF & 14,09 & 13,99 & 14,73 & 42,81 & 14,27 \\
$\mathbf{9}$ & MERK & 24,08 & 21,87 & 18,64 & 64,59 & 21,53 \\
$\mathbf{1 0}$ & TSPC & 9,97 & 8,97 & 6,84 & 25,78 & 8,59 \\
$\mathbf{1 1}$ & UNVR & 40,75 & 35,28 & 35,19 & 111,22 & 37,07 \\
Maksimum & 40,75 & 35,28 & 35,19 & 111,22 & 37,07 \\
Minimum & 3,85 & 4,9 & 5,75 & 14,5 & 4,83 \\
\hline
\end{tabular}

Sumber: idx.co.id. Data diolah, 2020

Tabel 2 menunjukkan 55 variasi Return On Assets dari 11 emiten sektor industri barang konsumsi di Bursa Efek Indonesia Tahun 2017-2019. Return on assets yang tinggi menggambarkan bahwa kemampuan perusahaan menghasilkan laba bersih yang tinggi, dan hal tersebut tentunya akan sangat disenangi oleh investor, dan akan menaikkan harga saham.

Return on assets tertinggi Tahun 2017-2019 dimiliki oleh UNVR, yakni sebesar 38,10\% pada tahun $2012,38,86 \%$ pada tahun 2013 , $40,75 \%$ pada tahun 2014, 35,28\% pada tahun 2015 dan pada tahun 2016 sebesar 35,19\%. Hal ini berarti setiap Rp 100 dari asset perusahaan yang digunakan emiten mampu memberikan keuntungan sebesar presentase yang ada. Return On Assets terendah Tahun 2017-2019 dimiliki oleh emiten INDF pada Tahun $2017,4,90 \%$ pada Tahun 2018 dan 5,75\% pada Tahun 2019.

b. Return on Equity (ROE)

Pada bagian ini akan dideskripsikan Return on Equity (ROE) 11 perusahaan sampel selama periode penelitian yakni pada Tahun 2017-2019, sehingga dapat diketahui perkembangan Return on Equity pada masing-masing emiten selama periode penelitian. Return on Equity merupakan perbandingan antara laba bersih perusahaan dengan modal sendiri perusahaan tersebut. Return on Equity menilai sejauh mana suatu perusahaan mempergunakan sumber daya yang dimiliki untuk mampu memberikan laba atas ekuitas. Perkembangan profitabilitas dapat dikatakan baik apabila ROE stabil naik setiap tahunnya. Sebaliknya apabila Return on Equity (ROE) mengalami penurunan disetiap tahunnya, maka 
profitabilitas perusahaan tersebut dikatakan

buruk. Berikut akan diuraikan pada Tabel 10

Tabel 3. Kinerja Return On Equity Emiten Sektor Industri Barang Konsumsi 2017-2019 (\%)

\begin{tabular}{clrrrrr}
\hline NO & EMITEN & $\mathbf{2 0 1 7}$ & $\mathbf{2 0 1 8}$ & $\mathbf{2 0 1 9}$ & Jumlah & Rata-rata \\
\hline $\mathbf{1}$ & DLTA & 37,94 & 22,6 & 25,14 & 85,68 & 28,56 \\
$\mathbf{2}$ & ICBP & 17,44 & 18,46 & 19,65 & 55,55 & 18,52 \\
$\mathbf{3}$ & INDF & 12,08 & 11,29 & 11,34 & 34,71 & 11,57 \\
$\mathbf{4}$ & MLBI & 42,3 & 65,71 & 19,36 & 127,37 & 42,46 \\
$\mathbf{5}$ & GGRM & 16,07 & 16,99 & 16,65 & 49,71 & 16,57 \\
$\mathbf{6}$ & HMSP & 74,2 & 32,28 & 36,66 & 143,14 & 47,71 \\
$\mathbf{7}$ & DVLA & 8,56 & 10,7 & 13,44 & 32,7 & 10,90 \\
$\mathbf{8}$ & KLBF & 21,47 & 19,05 & 18,89 & 59,41 & 19,80 \\
$\mathbf{9}$ & MERK & 33 & 31,43 & 26,42 & 90,85 & 30,28 \\
$\mathbf{1 0}$ & TSPC & 14,21 & 13,41 & 11,36 & 38,98 & 12,99 \\
$\mathbf{1 1}$ & UNVR & 27,97 & 21,48 & 26,64 & 76,09 & 25,36 \\
Maksimum & $\mathbf{7 4 , 2}$ & $\mathbf{6 5 , 2 1}$ & $\mathbf{3 6 , 6 6}$ & 176,07 & 58,69 \\
Minimum & $\mathbf{8 , 5 6}$ & $\mathbf{1 0 , 7}$ & $\mathbf{1 1 , 3 4}$ & 30,6 & 10,20 \\
\hline
\end{tabular}

Sumber: idx.co.id data diolah. 2020

Tabel 10 menunjukkan variasi Return On Equity dari 11 emiten sektor industri barang konsumsi di Bursa Efek Indonesia Tahun 2017-2019. Return on equity yang tinggi menggambarkan bahwa kemampuan perusahaan dalam menghasilkan laba bersihnya tinggi, dan hal tersebut tentunya akan sangat disenangi oleh investor, dan akan menaikkan harga saham. Return on equity tertinggi Tahun 2017-2019 dimiliki oleh HMSP dan MLBI dengan tahun yang berbeda. ROE tertinggi yang dimiliki HMSP terdapat pada Tahun 2018 sebesar 74,20\% dan pada Tahun 2019 sebesar 36,66\%,

Hasil Uji t 
Tabel 3. Hasil Uji t Pengaruh Profitabilitas terhadap Harga Saham

Emiten Sektor Industri Barang Konsumsi Pada Tahun 2017

Coefficientsa

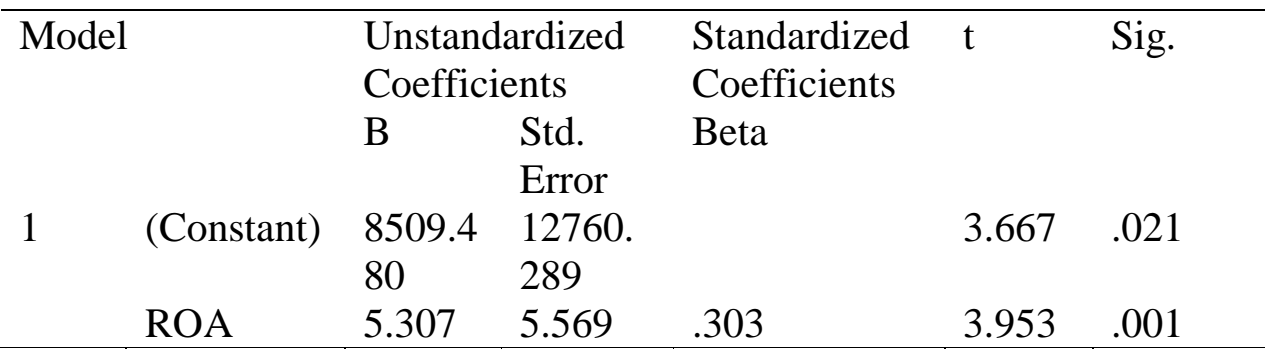

a. Dependent Variable: Harga.Saham

Sumber: data diolah , 2020

Tabel 11 menunjukkan bahwa variabel ROA memiliki nilai thitung sebesar 3,953 > t table dengan $\mathrm{N}=11$ sebesar 1.796 artinya terdapat pengaruh Return of Asset (ROA) terhadap harga saham pada tahun 2017. Signifikansi sebesar $0,001<0,05$. Nilai probabilitas signifikan sebesar 0,001 yakni kurang dari $\alpha$ sebesar 0,05 berarti bahwa koefisien regresi ROA sebesar 5.307 nyata atau signifikan. Koefisien regresi 5.307 memiliki arti bahwa setiap adanya kenaikan pada variabel independen ROA sebesar 0,1 atau $1 \%$ akan meningkatkan harga saham perusahaan sebesar 8509.480. Arah koefisien positif yang menjelaskan bahwa semakin tinggi profitabiltas perusahaan maka akan meningkatkan harga saham pada emiten sektor industri barang konsumsi di Bursa Efek Indonesia, maka hipotesis diterima.

Nilai ROA sebesar 5.307 yang berarti variabel Return on Asset (ROA) berpengaruh positif terhadap harga saham, artinya apabila ROA meningkat maka harga saham akan meningkat dan sebaliknya apabila ROA menurun maka harga saham akan menurun. Dilihat dari nilai signifikan < 0,05 atau sebesar 0,001 maka pengaruh Return on Asset (ROA) terhadap harga saham menunjukkan angka yang signifikan, sehingga pengaruh ROA terhadap harga saham pada tahun 2017 adalah nyata.

\begin{tabular}{|c|c|c|c|c|c|c|}
\hline \multicolumn{7}{|c|}{$\begin{array}{l}\begin{array}{l}\text { Emiten Sektor Industri Barang Konsumsi Pada Tahun } 2018 \\
\text { Coefficients }\end{array}\end{array}$} \\
\hline \multicolumn{2}{|c|}{ Model } & \multicolumn{2}{|c|}{ Unstandardized Coefficients } & \multirow{2}{*}{$\begin{array}{l}\text { Standardized } \\
\text { Coefficients } \\
\text { Beta }\end{array}$} & \multirow{2}{*}{$\begin{array}{l}\mathrm{T} \\
.290\end{array}$} & \multirow{2}{*}{$\begin{array}{l}\text { Sig. } \\
\quad 021\end{array}$} \\
\hline 1 & (Constant) & $\begin{array}{c}B \\
4521.653\end{array}$ & $\begin{array}{l}\text { Std. Error } \\
15569.128\end{array}$ & & & \\
\hline & ROA & 8.964 & 8.271 & .340 & 3.084 & .000 \\
\hline
\end{tabular}

Tabel 3 menunjukkan bahwa variabel ROA memiliki nilai t hitung sebesar 3,084 > t table dengan $\mathrm{N}=11$ sebesar 1.796 artinya terdapat pengaruh Return of Asset (ROA) terhadap 
harga saham pada Tahun 2018. Signifikansi sebesar $0,001<0,05$. Nilai probabilitas signifikan sebesar 0,001 yakni kurang dari $\alpha$ sebesar 0,05 berarti bahwa koefisien regresi ROA sebesar 8.964 nyata atau signifikan. Koefisien regresi 8.964 memiliki arti bahwa setiap adanya kenaikan pada variabel independen ROA sebesar 8.964 akan meningkatkan harga saham perusahaan sebesar 4521.653
Nilai ROA tahun 2018 sebesar 8.964 yang berarti variabel Return on Asset (ROA) berpengaruh positif terhadap harga saham, artinya apabila ROA meningkat maka harga saham akan meningkat dan sebaliknya apabila ROA menurun maka harga saham akan menurun. Dilihat dari nilai signifikan < 0,05 atau sebesar 0,001 maka pengaruh Return on Asset (ROA) terhadap harga saham menunjukkan angka yang signifikan, sehingga pengaruh ROA terhadap harga saham pada tahun 2018 adalah nyata



Tabel 13 menunjukkan bahwa variabel ROA memiliki nilai t hitung sebesar 2,630 > t table dengan $\mathrm{N}=11$ sebesar 1.796 artinya terdapat pengaruh Return of Asset (ROA) terhadap harga saham pada Tahun 2019. Signifikansi sebesar $0,003<0,05$. Nilai probabilitas signifikan sebesar 0,001 yakni kurang dari $\alpha$ sebesar 0,05 berarti bahwa koefisien regresi ROA sebesar 4.571 nyata atau signifikan. Koefisien regresi 4.571 memiliki arti bahwa setiap adanya kenaikan pada variabel independen ROA sebesar 4.571 akan meningkatkan harga saham perusahaan sebesar 11261.468
Nilai ROA tahun 2019 sebesar 4.571 yang berarti variabel Return on Asset (ROA) berpengaruh positif terhadap harga saham, artinya apabila ROA meningkat maka harga saham akan meningkat dan sebaliknya apabila ROA menurun maka harga saham akan menurun. Dilihat dari nilai signifikan sebesar $0.003<0,05$ maka pengaruh Return on Asset (ROA) terhadap harga saham menunjukkan angka yang signifikan, sehingga pengaruh ROA terhadap harga saham pada tahun 2019 adalah nyata.

\section{Hasil Uji R2}

Tabel 6 Hasil Uji-R² Pengaruh Profitabilitas terhadap Harga Saham Emiten Industri Barang Konsumsi Tahun 2017 


\begin{tabular}{lrrrr}
\hline Model & $\mathrm{R}$ & $\mathrm{R}$ Square & \multicolumn{1}{c}{$\begin{array}{c}\text { Adjusted } \mathrm{R} \\
\text { Square }\end{array}$} & \multicolumn{1}{c}{$\begin{array}{c}\text { Std. Error of } \\
\text { the Estimate }\end{array}$} \\
1 & $.303^{\mathrm{a}}$ & .092 & -.009 & 24201.897 \\
\hline
\end{tabular}

a. Predictors: (Constant), ROA

Tabel 6 menunjukkan nilai koefisien determinasi $\left(\mathrm{R}^{2}\right)$ sebesar 0,092 atau 9,2\% hal ini berarti $9,2 \%$ variabel harga saham mampu dijelaskan oleh variabel independen yaitu ROA, sedangkan sisanya sebesar 90,8\% dijelaskan oleh faktor-faktor lainnya di luar model regresi dalam penelitian ini

\section{KESIMPULAN}

Penelitian ini dilakukan untuk melihat perkembangan kinerja harga saham, rasio profitabilitas dan juga untuk mengkaji pengaruh rasio profitabilitas terhadap harga saham pada perusahaan manufaktur sektor industri barang konsumsi yang terdaftar di Bursa Efek Indonesia Periode Tahun 20172019. Berdasarkan hasil penelitian, maka dapat disimpulkan sebagai berikut :

Return On Asset (ROA) berpengaruh positif terhadap harga saham perusahaan sektor industri barang konsumsi. Pada Tahun 2017 Variabel ROA memiliki nilai t hitung sebesar 3,953 > t table dengan $\mathrm{N}=11$ sebesar 1.796 artinya terdapat pengaruh Return of Asset (ROA) terhadap harga saham pada tahun 2017. Pada Tahun 2018 variabel ROA memiliki nilai thitung sebesar 3,084 > t table 1.796 artinya terdapat pengaruh Return of Asset (ROA) terhadap harga saham dan pada tahun 2019 nilai t hitung sebesar 2,630 >t table dengan $\mathrm{N}=11$ sebesar 1.796 artinya terdapat pengaruh Return of Asset (ROA) terhadap harga saham pada Tahun 2019.
Nilai koefisien determinasi $\left(\mathrm{R}^{2}\right)$ Tahun 2017 sebesar 0,092 atau 9,2\% hal ini berarti $9,2 \%$ variabel harga saham mampu dijelaskan oleh variabel independen yaitu ROA. Tahun 2018 sebesar $11,5 \%$ dan pada tahun 2019 sebesar 4,2\% variabel harga saham mampu dijelaskan oleh independen yaitu ROA.

\section{UCAPAN TERIMAKASIH}

Terimakasih kepada Universitas Sang Bumi Ruwa Jurai yang telah berkontribusi dalam penelitian ini

\section{DAFTAR PUSTAKA}

Fahmi, Irham. 2012. Analisis Kinerja Keuangan, Bandung: Alfabeta

Fahmi, Irham. 2013. Analisis Laporan Keuangan. Bandung: Alfabeta

Hisbullah, Mohammad Rizqi. 2021. "PENGARUH PROFITABILITAS TERHADAP HARGA SAHAM PERUSAHAAN SEKTOR INDUSTRI BARANG DAN KONSUMSI DI BEI TAHUN 20172020." Jurnal Ilmu Manajemen 9 No. 2:10

Husnan, Suad. 2005. Dasar-dasar Teori Portofolio dan Analisis Sekuritas. Yogyakarta: UPP AMP YPKN.

Ircham,dkk. 2014. Pengaruh Struktur Modal dan Profitabilitas Terhadap Harga Saham (Studi Pada Perusahaan Makanan dan Minuman yang terdaftar 
di Bursa Efek Indonesia Tahun 20092012)

Jumingan. 2006. "Analisa Laporan Keuangan”. Jakarta : Bumi Aksara

Murdijaningsih, Tjahjani, and Minadi Wijaya. 2018. "PENGARUH PROFITABILITAS TERHADAP HARGA SAHAM PADA PERUSAHAAN MANUFAKTUR SEKTOR INDUSTRI BARANG KONSUMSI YANG TERDAFTAR
DI BURSA EFEK INDONESIA PERIODE TAHUN 2015-2017." Jurnal MIMB 15 No. 2:12.

Wyanov, Uska. 2012. Pengaruh Pangsa Pasar Terhadap Return Saham Sektor Industri Barang Konsumsi di BEI Periode 2008-2011. Skripsi. Universitas Lampung. 